\title{
OBITUARY \\ Obituary of Phillip Harris
}

\section{Spinal Cord (2014) 52, 88; doi:10.1038/sc.2013.153}

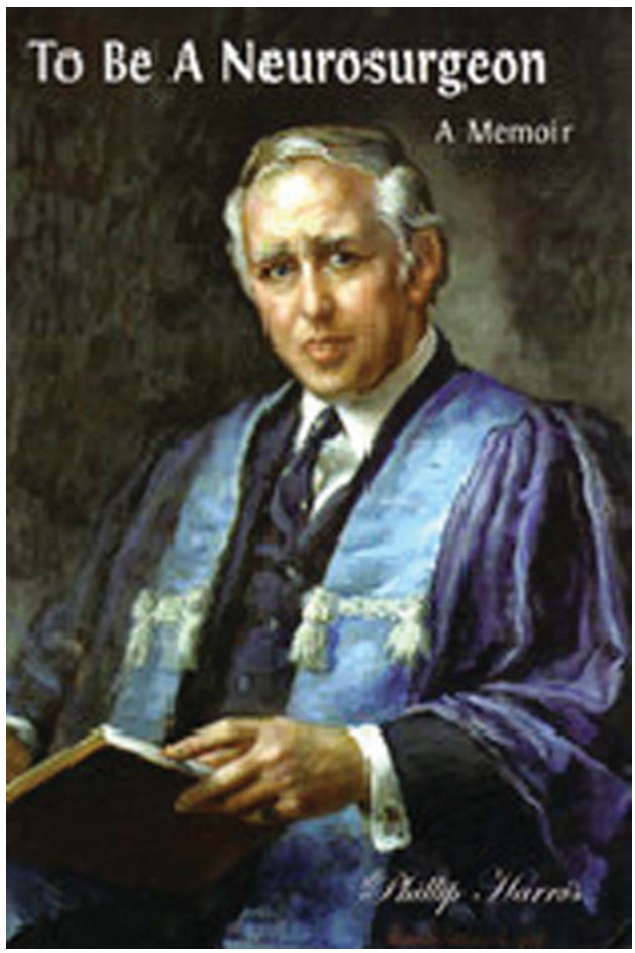

Phillip Harris died on Friday, 22 February 2013, at Western General Hospital.

He was born in Edinburgh on the 28th March 1922.

During his education at the School of Medicine of the Royal Colleges of Edinburgh, he excelled as a medical student and won many prizes. He obtained the license to practice Surgery and Medicine in 1944. He became a Fellow of the Royal College of Physicians of Edinburgh \& Royal College of Surgeons of both Edinburgh and Glasgow.

He trained in Neurosurgery in Bangour Hospital and in the National Hospital for Nervous diseases, Queen Square London. During his career he held many offices often simultaneously. He was Consultant Neurosurgeon in Edenhall Hospital, Musselborough, where he was also in charge of the Spinal Unit between 1948 and 1987, and to the Murrayfield Hospital, Edinburgh, between 1984 and 1992. Throughout this period he pioneered in the field of epilepsy and spinal diseases. He trained more than one generation of neurosurgeons both in the United Kingdom and overseas, many of his students becoming under his mentorship also eminent in their own right.
Phillip Harris, was active as organizer of training, planning and development of Neurosciences services in the United Kingdom and overseas. He was Medical Adviser for the planning, building, staffing and functioning of Spinal injuries Centres in New Delhi, Cairo, Nicosia, Thessaloniki, Riyadh and Scotland. He was a founder member of many societies ISCOS (formerly IMSoP) and the Scottish Branch of the Scottish Epilepsy Society. He was a Council member of the Scottish Society of the History of Medicine. Phillip was on the Editorial Board as member, assistant Editor and chief Editor of a number of medical journals, including our Journal 'Spinal Cord' (formerly Paraplegia).

Phillip was a well sought-after guest lecturer and Chairman of sessions in national and international congresses. He travelled widely lecturing throughout the globe, including Argentina, Canada, Cyprus, Hong Kong, India, Israel, Iran, Burma, Bolivia, Peru, Japan and the United States America. He held the title of visiting Professor in universities in many of these countries.

His activity in research resulted in 86 peer reviewed publications in journals and 13 chapters and books. His last book 'How to be a Neurosurgeon' crowns not only his professional career but also his humanity, his sense of humour and most of all his love for his wife Sheelagh, his children Francis and Harvey, and his grandchildren Abigail, Samantha, Shiona and Alasdair.

He received the Fellowship of the Royal Society of Scotland, the prestigious Paul Harris Fellowship and the offer of the Chair of Neurosurgery in Harvard University in Massachusetts, USA, which he felt he had to decline to continue to serve his patients in Scotland.

Sir David Carter wrote: Neurosurgery has benefited greatly from the contribution of Phillip Harris and there can be no doubting his particular contribution to the strength of neurosurgery and related neurosciences in Edinburgh. He writes with the authority of one who worked extensively at the growing edge of his specialty, who has engaged internationally with all that is best in his field, and who has made numerous scholarly contributions to neurosurgery and in particular to our understanding and management of disorders of the spinal cord. His curiosity has not been confined to neurosurgery, however, and forays into the modern field of stem cell research and thoughts of Rembrandt as an anatomist or Mahler as a composer.

Phillip's motto was 'work is fun'. He kept working and he was mentally and physically active to the very end. His contributions will outlive him for many decades to come.

WS El Masri, P Dollfus and J-J Wyndaele University Antwerp, Universitair Ziekenhuis Antwerpen, Antwerp, Belgium E-mail: Jean-Jacques.Wyndaele@uza.be 